\title{
Evaluation of a 3D Printed Female Anatomical Model for the Hands on Training of Trans-Obturator Tape (TOT) and Tension Free Vaginal Tape (TVT) Sling Procedures
}

\author{
Evaluación de un Modelo Anatómico Femenino Impreso en 3D para el Entrenamiento Práctico \\ de los Procedimientos de Cinta Trans-Obturadora (TOT) y Cinta Vaginal sin Tensión (TVT)
}

\author{
Ilkan Tatar; Ilker Selçuk \& Emre Huri
}

TATAR, I.; SELÇUK, I. \& HURI, E. Evaluation of a 3D printed female anatomical model for the hands on training of trans-obturator tape (TOT) and tension free vaginal tape (TVT) sling procedures. Int. J. Morphol., 38(2):292-298, 2020.

SUMMARY: Trans-obturator tape (TOT) and tension free vaginal tape (TVT) procedures are efficient treatment options, which reduce the surgical complications and provide adequate support to urethra in case of increased abdominal pressure to prevent stress urinary incontinence (SUI). The aim of this study is to evaluate the effect and efficacy of 3D printed female anatomical model on the training of TOT and TVT procedures. A 3D printed female anatomical model was produced for MedTRain3DModSim, Erasmus+ European Union project led by Turkey with the participation of Greece, Italy, Czech Republic and South Korea. Face and content validities of the model evaluated by the participants and the experts respectively. During two learning \& teaching \& training activities and a multiplier event of the project between 2016 and 2018; 41 medical students, 30 residents and 19 specialists of urology and gynecology were educated and performed TOT and TVT procedures with this model under the mentorship of 3 experts. All participants were assessed and scored for their achievement on both procedures with model according to 7 parameters by the experts. There was no statistical difference between the students and residents for each parameter. All the parameters of the students and specialists were statistically different. 3D anatomical models produced from real data and mimicking different types of tissues are suitable for basic anatomy education of students and residents, hands on training for junior surgeons before cadaveric courses in hybrid education system, surgical planning of the surgeons and informing the patients before the operation.

KEY WORDS: 3D printed; Female anatomical model; Trans-obturator tape; Tension free vaginal tape; Stress urinary incontinence.

\section{INTRODUCTION}

Training of the surgical skills are complex issue regarding to medical education. With increasing public awareness regarding medical errors and patient safety, it is need of the hour to develop new methods for training in medical education (Aggarwal, 2016). The current apprenticeship or "see one, do one, teach one" model is insufficient because trainees learn by practicing on real patients, which is particularly an issue when performing procedures. Residents have expressed that they do not feel adequately trained to perform procedures safely by themselves. Because of high-risk and stress environments, lack of practice on a regular basis, especially with uncommon events/ procedures and/or complications, lack of rigorous evaluation, readjustment and correction of problems, limited knowledge of the impact that medical training has on patient safety, unlike other high-reliability industries, we train on real patients and must "assume" the inherent risks and lack of training in team interactions, crisis management, and conflict resolution (Rodriguez-Paz et al., 2009). Following the paradigm of "precision medicine", contemporary urologic surgery has entered a technology-driven era of "precision surgery", which entails a range of surgical procedures tailored to combine maximal treatment efficacy with minimal impact on patient function and health related quality of life (Autorino et al., 2017).

\footnotetext{
1 Department of Anatomy, Faculty of Medicine, Hacettepe Univesity, Ankara, Turkey ORCID ID: 0000-0003-2532-8582

2 Specialist of Gynecologic-Oncology, Zekai Tahir Burak Research and Educational Hospital, Ankara, Turkey ORCID ID: 0000-0003-0499-5722

3 Department of Urology, Faculty of Medicine, Hacettepe Univesity, Ankara, Turkey ORCID ID: 0000-0001-5563-4527

FUNDING The 3D model evaluated in this paper was produced by MedTRain3DModsim Erasmus+ European Union Project, 2016-1-TR01-KA203-

034929, funded by Ministry of Foreign Affairs, National Agency of Turkey.
} 
In this setting, 3D virtual reconstruction of 2D crosssectional imaging has been increasingly adopted to aid the surgeon in better understanding surgical anatomy. Moreover, these reconstructions may be printed by using dedicated 3D printers to create models easily handled by surgeons and patients. The availability of these high-quality $3 \mathrm{D}$ virtual or printed reconstructions of "target" organs allows the surgeon to acquire cognitive information before the procedure (Porpiglia et al., 2018). Several 3D printing methods have been developed for, which a variety of applications on medicine have been found, including creating prototypes of new products, fabricating architectural models, and rapidly generating replacement parts and other products for patients (Colaco et al., 2018). In order to plan, test, and practice surgical procedures before they are used in patients it is necessary to have access to organ models. 3D organ models are particularly useful in surgical urology because miniaturized medical equipment both for endoscopic (including laparoscopic) and open surgical procedures are often used (Adam, 2016).

Urinary incontinence is defined as a condition of involuntary loss of urine. The three most common types are: (1) SUI; (2) urge urinary incontinence (UUI); (3) mixed urinary incontinence (MUI), denoting the combination of both SUI and UUI (Capobianco et al., 2018). According to Hunskaar et al. (2003) the prevalence of each type of urinary incontinence in noninstitutionalized women is $49 \%, 21 \%$ and $29 \%$, respectively. Other estimates of the prevalence of SUI range between $10 \%$ and $40 \%$ of the post-menopausal female population (Hunskaar et al.). One of the two most common current techniques using for SUI surgical treatment was TVT, introduced in the 1990s by Ulmsten \& Petros (1995), in which the mesh is introduced by vaginal incision, then directed towards the retropubic space, and then passed out from the abdominal wall into the suprapubic area. Second one TOT was developed in an attempt to address these complications (Delorme, 2001). In contrast to the retro-pubic approach, the trans-obturator approach involves the passage of a sub-urethral sling through the medial aspect of the obturator membrane, the advantage being that there is a greater distance to vital structures such as the bladder and intra-peritoneal contents such as bowel. In addition, due to the comparatively less acute angle of the sling, it was suggested that the trans-obturator sling could potentially be less obstructive to urine flow through the urethra (Barry et al., 2007).

In recent years, the effort of the application of hybrid educational modules including 3D virtual and printed anatomical models, simulators, animal models and cadavers to the surgical skills trainings has been improved. Here, we aimed to evaluate the effect and efficacy of 3D printed female anatomical model on the training of TOT and TVT procedures.

\section{MATERIAL AND METHOD}

This study was performed under the umbrella of MedTRain3DModsim Erasmus+ European Union Project (starting date October 2016 and finishing date October 2018) was led by Hacettepe University, Turkey and the partner organizations were Chosun University, South Korea; Charles University, Czech Republic; Rome 3 University, Italy and Hellenic Urological Association, Greece. Its full name is 'Novel Educational Materials in Medical Training with 3D Modeling Application and Simulation Modalities (Virtual Reality and Augmented Reality)'. It was the first project funded by National Agency of Turkey to extract and reconstruct 3D realistic anatomical models from Digital Imaging and Communications in Medicine (DICOM) images of CT with variable software packages and to print or simulate those, three dimensionally for educational purposes.

We produced skeleton of female anatomical model from DICOM images and added required muscular, neural and vascular anatomical structures for especially TOT and TVT slings procedures on it (Fig. 1). After completion of the production, three experts (an anatomist, a gynecologist and a urologist) assessed and validated Content Validity of the model depending on its appropriateness for procedures training guidelines. Face Validity, which includes nonexpert's opinions regarding the realism of the model, was also assessed and validated by the experts and all participants using 5 responses (strongly agree/agree/don't know/disagree/strongly disagree) Likert's scale (Table I).

During two learning \& teaching \& training activities and a multiplier event of the project, which were held between 2016 and 2018 in Ankara and Hatay, Turkey respectively; 41 medical students, 30 residents and 19 specialists of urology and gynecology were educated and performed TOT and TVT procedures with this model under the mentorship of 3 experts. All participants were assessed and scored for their achievement on both procedures with model according to 7 parameters by the experts.

Scoring of first parameter, anatomical landmarks identification, was done according to participant's success to identify these landmarks, which were labeled in Figure 1 , on model before performing the procedure. Performing anterior vaginal wall dissection, our second parameter, is a common step for both procedures and should be vertical and suburethrally at midurethral level. After this in TOT, dissection carried out to the pubic arch bilaterally; more specifically, towards the anterior obturator notch in the obturator foramen. Two small incisions were made at the 

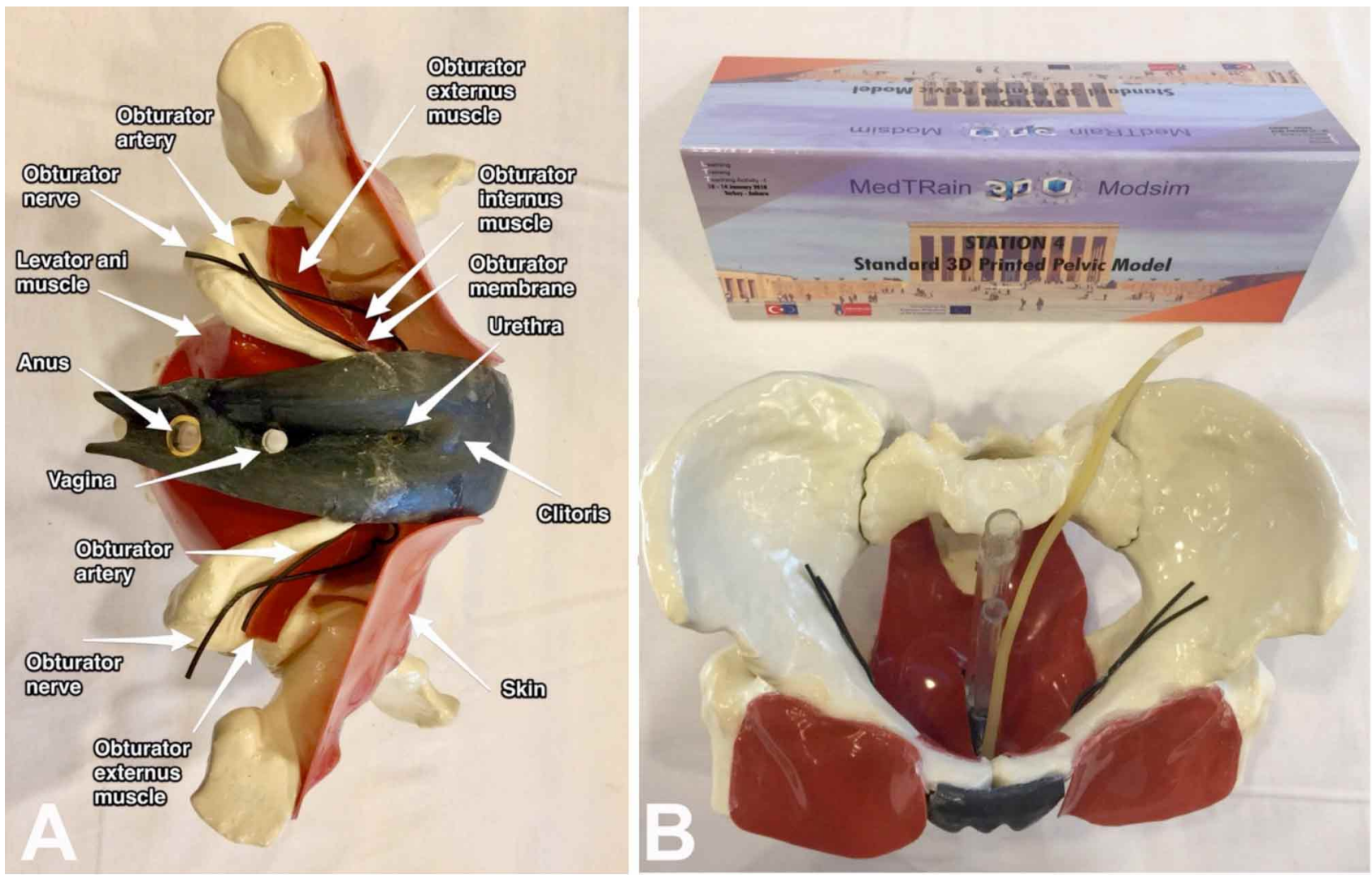

Fig. 1. Photo of 3D printed female anatomical model produced by MedTRain3DModsim Erasmus+ European Union Project (A) Labeled with anatomical landmarks (B) Seen from superior for better visualization of the midline structures in pelvis.

Table I. General assessment of model's face validity.

\begin{tabular}{lccccc}
\hline \multicolumn{1}{c}{ Variable } & Mean & Median & SD & Min & Max \\
\hline 3D Pelvic model usefulness & 4.26 & 4 & 0.72 & 3 & 5 \\
3D Pelvic model realism & 3.95 & 4 & 0.81 & 2 & 5 \\
3D Pelvic model overall & 4.26 & 4 & 0.69 & 3 & 5 \\
\hline
\end{tabular}

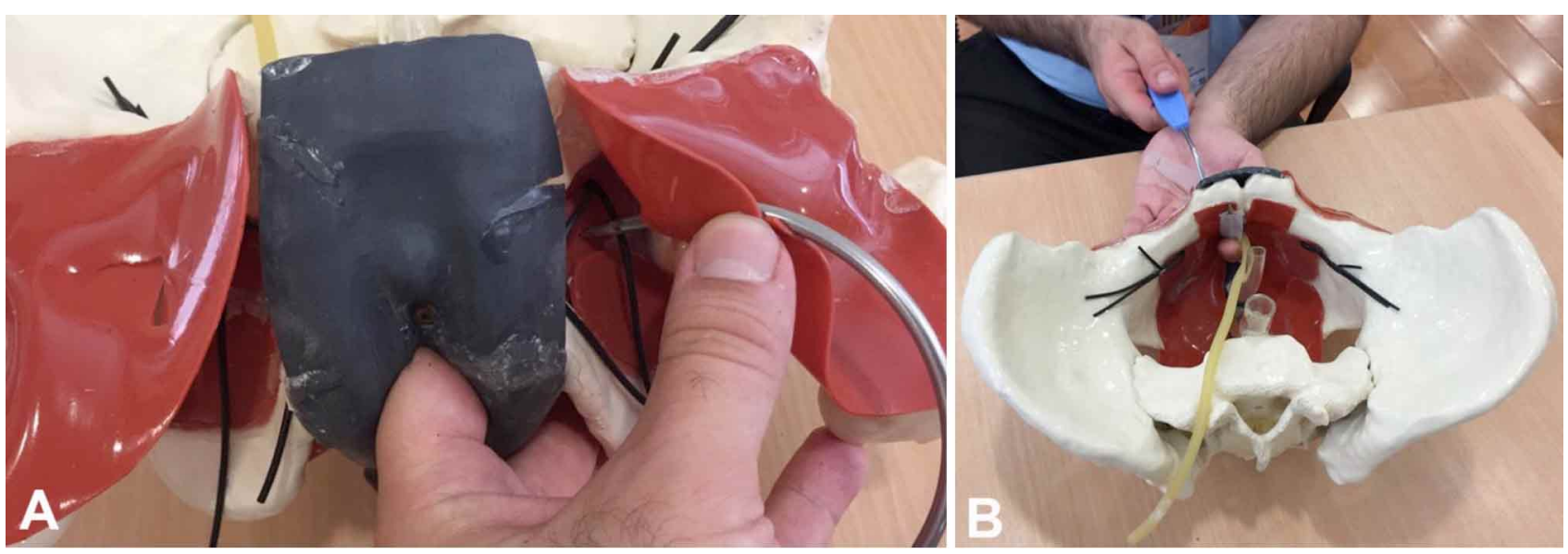

Fig. 2. (A) Photo of outside to inside TOT needle insertion performance on model. (B) Photo of TVT needle insertion performance on model. 
inner thigh at the level of the clitoris and 1.5 centimeters below the adductor longus tendon bilaterally. A helical TOT introducer was passed from the inner thigh incision through the obturator foramen until it touches the opposite index finger. Then the introducer was guided through the suburethral incision. This maneuver called outside to inside. If it was performed starting from suburethral incision to inner thigh incision, it called inside to outside. The same procedure was repeated on the opposite side. Participants performed and their performance was assessed outside to inside maneuver on the right (our third parameter), inside to outside on the left (our fourth parameter) (Fig. 2A).

After vaginal wall incision in TVT, dissection carried out laterally to the ischiopubic ramus and TVT introducer was passed from the vaginal entry point through the retropubic space to exit through the suprapubic incision. Participants performed and their performance was assessed similarly as TOT that outside to inside on the right (our fifth parameter), inside to outside on the left (our sixth parameter) (Fig. 2B). Good positioning of the tape midurethrally and their hands positions during the maneuver was assessed as a seventh parameter.
These scores were pointed by the trainers in a blind fashion, without any knowledge of the participant's category. All the values were analyzed by Kruskal-Wallis Test. One-by-one Mann Whitney-U test was performed to differentiate where there is a statistically significant difference between the categories. Value of $p \leq 0.05$ was accepted for statistical significance. SPSS 21 was used for statistical analyses.

\section{RESULTS}

Assessed performances for each parameter and comparison of the groups were seen in Table II. There was a statistically significant difference between the compared groups of student, resident and specialist within all the parameters. Statistically significant difference between the categories was seen Table III. There was no any statistical difference between the student's and resident's category for each parameter. Since these activities are based on practical hand movements, while learning the initial steps of trans-obturator and trans-vaginal tape procedure;

Table II. Assessed performances for each parameter and comparison of three groups.

\begin{tabular}{|c|c|c|c|c|c|c|c|}
\hline Parameter & Cat egory & Mean & Median & Min & Max & SD & $\mathrm{p}$ \\
\hline 1-Identify anatomical & Student & 4.21 & 4.5 & 2 & 5 & 0.91 & \\
\hline \multirow[t]{3}{*}{ landmarks in pelvic model } & $(n=41)$ & & & & & & \\
\hline & $\begin{array}{l}\text { Resident } \\
(\mathrm{n}=30)\end{array}$ & 4.46 & 5.0 & 2 & 5 & 0.71 & 0.009 \\
\hline & $\begin{array}{l}\text { Specialist } \\
(\mathrm{n}=19)\end{array}$ & 4.89 & 5.0 & 4 & 5 & 0.31 & \\
\hline \multirow{3}{*}{$\begin{array}{l}\text { 2-Perform anterior vaginal } \\
\text { wall dissection }\end{array}$} & Student & 4.44 & 4.5 & 2 & 5 & 0.70 & \\
\hline & Resident & 4.57 & 5.0 & 2 & 5 & 0.89 & 0.000 \\
\hline & Specialist & 5.0 & 5.0 & 5 & 5 & 0.0 & \\
\hline \multirow{3}{*}{$\begin{array}{l}3 \text {-Perform right transobturator } \\
\text { route of needle }\end{array}$} & Student & 4.34 & 4.0 & 2 & 5 & 0.76 & \\
\hline & Resident & 4.41 & 5.0 & 1 & 5 & 0.92 & 0.029 \\
\hline & Specialist & 4.84 & 5.0 & 4 & 5 & 0.37 & \\
\hline \multirow{3}{*}{$\begin{array}{l}\text { 4-Perform left transobturator } \\
\text { route of needle }\end{array}$} & Student & 4.17 & 4.0 & 2 & 5 & 0.80 & \\
\hline & Resident & 4.44 & 5.0 & 2 & 5 & 0.86 & 0.013 \\
\hline & Specialist & 4.74 & 5.0 & 4 & 5 & 0.45 & \\
\hline \multirow{3}{*}{$\begin{array}{l}\text { 5-Perform right transvaginal } \\
\text { route of needle }\end{array}$} & Student & 4.15 & 4.0 & 3 & 5 & 0.72 & \\
\hline & Resident & 4.32 & 5.0 & 1 & 5 & 0.94 & 0.005 \\
\hline & Specialist & 4.79 & 5.0 & 4 & 5 & 0.41 & \\
\hline \multirow{3}{*}{$\begin{array}{l}\text { 6-Perform left transvaginal } \\
\text { route of needle }\end{array}$} & Student & 4.09 & 4.0 & 2 & 5 & 0.72 & \\
\hline & Resident & 4.35 & 5.0 & 3 & 5 & 0.77 & 0.000 \\
\hline & Specialist & 4.84 & 5.0 & 4 & 5 & 0.37 & \\
\hline \multirow{3}{*}{$\begin{array}{l}\text { 7-Good positioning and hand's } \\
\text { position }\end{array}$} & Student & 4.24 & 4.0 & 3 & 5 & 0.58 & \\
\hline & Resident & 4.49 & 5.0 & 3 & 5 & 0.68 & 0.000 \\
\hline & Specialist & 4.95 & 5.0 & 4 & 5 & 0.22 & \\
\hline
\end{tabular}


students and residents got similar scores. All the parameters for the student's and specialist's category were statistically different. The previous experience of specialists might be the most probable factor of this result.

\begin{tabular}{lccc}
\multicolumn{2}{l}{ Table III. Comparision of each parameter between the groups. } \\
\hline Parameter & $\begin{array}{c}\mathrm{p} \text { value } \\
\text { Student-Resident }\end{array}$ & $\begin{array}{c}\mathrm{p} \text { value } \\
\text { Student-Specialist }\end{array}$ & $\begin{array}{c}\mathrm{p} \text { value } \\
\text { Resident-Specialist }\end{array}$ \\
\hline 1-Identify anatomic landmarks in pelvic model & 0.316 & 0.003 & 0.01 \\
2-Perform anterior vaginal wall dissection & 0.166 & 0.000 & 0.000 \\
3-Perform right transobturator route of needle & 0.409 & 0.008 & 0.050 \\
4-Perform left transobturator route of needle & 0.061 & 0.005 & 0.280 \\
5-Perform right transvaginal route of needle & 0.146 & 0.001 & 0.059 \\
6-Perform left transvaginal route of needle & 0.189 & 0.000 & 0.016 \\
7-Good positioning and hand's position & 0.594 & 0.000 & 0.000 \\
\hline
\end{tabular}

\section{DISCUSSION}

The aim of TOT procedure is to place the mesh through the obturator foramen and underneath the mid part of the urethra with minimal damage to surrounding tissues. There are remarkable variations in the bony architecture of the female pelvis, and this variability may have an important effect on sling operations. Defined and demonstrated dissections are really helpful for understanding the surgical anatomy of the obturator foramen, pelvic floor and perineum is necessary to make a successful implantation of TOT and minimize morbidity. Huri et al. (2015) performed freshfrozen cadaveric dissections to demonstrate anatomical landmarks for TOT and summarized anatomical complications of it.

A graduating resident of gynecology and urology should be able to safely perform a urinary incontinence procedure. Casiano et al. (2012) reported that only $54 \%$ of recent graduates rated uro-gynecology experience as acceptable, with increasing the surgical volume the single most important factor needed to enhance training. Sabourin et al. (2012) studied to determine the effectiveness of a teaching module using simulation for the TVT procedure on procedural knowledge and skill on 25 obstetrics and gynecology (OBGYN) residents. They found a significant median improvement of $44 \%$ on the written examination and at least one point on each of the self-rated competence and knowledge scales were observed after the teaching module. Residents performed the insertion well at both examinations ( $89 \%$ and $90 \%$ ), regardless of surgical experience. More than $94 \%$ agreed the module was useful and improved their understanding of the procedure.
Chong et al. (2017) investigated the effect of additional cadaver laboratory use in training 32 OBGYN residents on TOT insertion. Surgical skills were assessed by placing one arm of the TOT trocar on a custom-designed pelvic model simulator while being graded by a Female Pelvic Medicine and Reconstructive Surgery board-certified proctor. After interventions, knowledge scores improved for both control and intervention groups [8.8\% for control group (1); $14.1 \%$ for intervention group (2)]; TOT insertion scores were significantly higher in group $2(6.76 / 15 \pm 2.54$ group $1 ; 10.24 / 15 \pm 2.73$ group $2, \mathrm{P}<0.01$ ); confidence scores improved in both groups. The pelvic model simulator was rated as the most useful method to learn TOT placement by group 1 . Group 2 rated TOT simulation $(47 \%)$ and cadaver laboratory $(41 \%)$. All trainees reported that the pelvic model was highly realistic.

We achieved some important outputs as the MedTRain3DModSim project team on urology training both anatomically and surgically. First one was experiencing 'the hybrid anatomy education', which includes theoretical lectures, basic anatomical models, animal models, 3D digital and printed models, virtual and physical simulators and cadaveric courses. When we looking at the southern-eastern European region, which includes Italy, Greece and Turkey, cadaver donation was limited and less than other regions of Europe. Usage of the printed and/or digital 3D anatomical models in the Anatomy education increased the content and quality of it and provided variety and diversity to limited educational materials because of the cadaver restriction. 
Second one was 'health sciences 3D modelling unit' idea, which was formed with the support of the Mustafa Kemal University after our multiplier event held in Antakya. This was the proof that our dissemination efforts will continue after the project. With this, achievement of the intellectual outputs to more people was provided. Third one was 'the integration of 3D medical modeling system in medical training curriculum'. We tried to reach this goal with our intellectual outputs, learning \& teaching \& training activities, multiplier event and dissemination courses.

We published a proper method to perform TOT and TVT needle (trocar) insertion with a cadaveric demonstration, which was performed at one of our disseminating events. We tried to depicted highly crucial role of cadaveric dissection courses in this hybrid anatomy education (Selçuk et al., 2019). We also demonstrated the role of cadaveric hands-on training model on surgical skills and confidence levels of surgeons during TOT surgery. A pre- and post-test evaluation to measure skills during the practice of the steps of TOT surgery was performed on 15 postgraduate urologists and gynecologists during a urogynecologic cadaveric dissection course includes theoretical lessons, full pelvic cadaveric dissection and TOT surgery on cadavers.

Good handling of the TOT needle, identifying the right place for groin incision, adequate size of groin incision, identifying the right place for incision at the anterior vagina, dissection of bladder pillars from the vagina, identifying the right place at the vaginal foramina for TOT needle insertion, and good placement of mesh were evaluated by the experts. The post-test scores were statistically significant for all parameters (Selçuk et al., 2018).

\section{CONCLUSION}

In this study as a first time, we scored students and compared them with residents and specialists to evaluate their surgical skills for relatively basic surgical procedures; TOT and TVT. According to our results; 3D anatomical models produced from real data and mimicking different types of tissues are suitable for basic anatomy education of students and residents, hands on training for junior surgeons before cadaveric courses in hybrid education system, surgical planning of the surgeons and informing the patients before the operation.

ACKNOWLEDGEMENTS. Author contributions. IT (Associate Professor of Anatomy, Hacettepe University
Faculty of Medicine Department of Anatomy) — project development, protocol development, data collection, data analysis, manuscript writing, approval of the manuscript. IS (Urogynecologist, Gynecologic Oncologist and Anatomy Ph. D. candidate, Ministry of Health Zekai Tahir Burak Women and Child Care Research and Education Hospital) - data analysis, manuscript writing. EH (Associate Professor of Urology, Hacettepe University Faculty of Medicine Department of Urology) - project development, protocol development, data collection, manuscript writing.

TATAR, I.; SELÇUK, I. \& HURI, E. Evaluación de un modelo anatómico femenino impreso en 3D para el entrenamiento práctico de los procedimientos de cinta trans-obturadora (TOT) y cinta vaginal sin tensión (TVT). Int. J. Morphol., 38(2):292-298, 2020.

RESUMEN: Los procedimientos de cinta transobturadora (TOT) y cinta vaginal sin tensión (TVT) son opciones de tratamiento eficientes, que reducen las complicaciones quirúrgicas y proporcionan un soporte adecuado a la uretra en caso de aumento de la presión abdominal para prevenir la incontinencia urinaria de esfuerzo (IUE). El objetivo de este estudio fue evaluar el efecto y la eficacia del modelo anatómico femenino impreso en 3D en el entrenamiento de los procedimientos TOT y TVT. Se produjo un modelo anatómico femenino impreso en 3D para MedTRain3DModSim, proyecto Erasmus + de la Unión Europea dirigido por Turquía con la participación de Grecia, Italia, la República Checa y Corea del Sur. Validez facial y de contenido del modelo fueron evaluados por los participantes y los expertos respectivamente. Durante dos actividades de aprendizaje, enseñanza y capacitación y un evento multiplicador del proyecto entre 2016 y 2018; 41 estudiantes de medicina, 30 residentes y 19 especialistas en urología y ginecología fueron capacitados y realizaron procedimientos TOT y TVT de este modelo bajo la tutoría de 3 expertos. Todos los participantes fueron evaluados y calificados por los expertos, por su logro en ambos procedimientos con el modelo de acuerdo con 7 parámetros. No hubo diferencia estadística entre los estudiantes y los residentes para cada parámetro. Todos los parámetros de los estudiantes y especialistas fueron estadísticamente diferentes. Los modelos anatómicos en 3D producidos a partir de datos reales e imitando diferentes tipos de tejidos son adecuados para la educación básica de anatomía de estudiantes y residentes. Además de ofrecer una capacitación práctica para los cirujanos antes de los cursos cadavéricos en el sistema educativo, y una planificación quirúrgica de los cirujanos e información para los pacientes antes de la cirugía.

PALABRAS CLAVE: Impresión 3D; Modelo anatómico femenino; Cinta trans-obturadora; Cinta vaginal sin tensión; Incontinencia urinaria de esfuerzo. 


\section{REFERENCES}

Aggarwal, S.; Choudhury, E.; Ladha, S.; Kapoor, P. M. \& Kiran, U. Simulation in cardiac catheterization laboratory: need of the hour to improve the clinical skills. Ann. Card. Anaesth., 19(3):521-6, 2016.

Autorino, R.; Porpiglia, F.; Dasgupta, P.; Rassweiler, J.; Catto, J. W.; Hampton, L. J.; Lima, E.; Mirone, V.; Derweesh, I. H. \& Debruyne, F. M. J. Precision surgery and genitourinary cancers. Eur. J. Surg. Oncol., 43(5):893-908, 2017

Barry, C.; Lim, Y. N.; Muller, R.; Hitchins, S.; Corstiaans, A.; Foote, A.; Greenland, H.; Frazer, M. \& Rane, A. A multi-centre, randomised clinical control trial comparing the retropubic (RP) approach versus the transobturator approach (TO) for tension-free, suburethral sling treatment of urodynamic stress incontinence: the TORP study. Int. Urogynecol. J. Pelvic Floor Dysfunct., 19(2):171-8, 2008.

Capobianco, G.; Madonia, M.; Morelli, S.; Dessole, F.; De Vita, D.; Cherchi, P. L. \& Dessole, S. Management of female stress urinary incontinence: a care pathway and update. Maturitas, 109:32-8, 2018.

Casiano, E. R.; Wendel Jr., G. D.; Congleton, M. J. \& Wai, C. Y. Urogynecology training and practice patterns after residency. J. Surg. Educ., 69(1):77-83, 2012

Chong, W.; Downing, K.; Leegant, A.; Banks, E.; Fridman, D. \& Downie. S. Resident knowledge, surgical skill, and confidence in transobturator vaginal tape placement: the value of a cadaver laboratory. Female Pelvic Med. Reconstr. Surg., 23(6):392-400, 2017.

Colaco, M.; Igel, D. A. \& Atala, A. The potential of 3D printing in urological research and patient care. Nat. Rev. Urol., 15(4):213-21, 2018.

Delorme, E. Transobturator urethral suspension: mini-invasive procedure in the treatment of stress urinary incontinence in women. Prog. Urol., 11(6):1306-13, 2001.

Hunskaar, S.; Burgio, K.; Diokno, A.; Herzog, A. R.; Hjälmås, K. \& Lapitan, M. C. Epidemiology and natural history of urinary incontinence in women. Urology, 62(4 Suppl. 1):16-23, 2003

Huri, E.; Ezer, M.; Aydog an, B.; Tatar, I’ \& Sargon, M. F. Anatomic transobturator tape (TOT) technique: clinical anatomic landmarks of obturator foramen on female cadavers. Anatomy, 9(1):38-41, 2015

Porpiglia, F.; Amparore, D.; Checcucci, E.; Autorino, R.; Manfredi, M.; Iannizzi, G.; Fiori, C. \& for ESUT Research Group. Current use of three-dimensional model technology in urology: a road map for personalised surgical planning. Eur. Urol. Focus, 4(5):652-6, 2018.

Rodriguez-Paz, J. M.; Kennedy, M.; Salas, E.; Wu, A. W.; Sexton, J. B.; Hunt, E.A. \& Pronovost, P. J. Beyond "see one, do one, teach one": toward a different training paradigm. Qual. Saf. Health Care, 18(1):638, 2009.

Sabourin, J. N.; Schulz, J. A. \& Flood, C. G. Improving resident competence and knowledge regarding tension-free vaginal tape procedure: an educational module. Female Pelvic Med. Reconstr. Surg., 18(5):268$73,2012$.

Selçuk, I’ .; Tatar, I’ . \& Huri, E. How to apply transobturator and transvaginal tape needles: a cadaveric demonstration study with anatomical landmarks. J. Clin. Obstet. Gynecol., 29(1):17-23, 2019.

Selçuk, I' :; Tatar, I' \& \& Huri, E. The Effect of Cadaveric Hands-On Training Model on Surgical Skills and Confidence for Transobturator Tape Surgery. J. Turk. Ger. Gynecol. Assoc., 20(4):243-6, 2018.

Ulmsten, U. \& Petros, P. Intravaginal slingplasty (IVS): an ambulatory surgical procedure for treatment of female urinary incontinence. Scand. J. Urol. Nephrol., 29(1):75-82, 1995.
Corresponding author:

Assoc. Prof. Ilkan Tatar, M.D.

Address: Hacettepe University

Faculty of Medicine

Department of Anatomy

06100 Sihhiye

Ankara

TURKEY

E-mail: ilkan@hacettepe.edu.tr

Received: 05-07-2019

Accepted: 05-09-2019 